\title{
PENERAPAN STRATEGI QUESTIONS STUDENTS HAVE (QSH) DALAM PEMBELAJARAN LANGSUNG UNTUK MENINGKATKAN HASIL BELAJAR MATEMATIKA SISWA KELAS X1 SMA NEGERI 2 BANGKO KABUPATEN ROKAN HILIR
}

(The Implementation of Questions Students Have (Qsh) Strategies in Direct Learning to Improve Mathematical Learning Outcomes of Class X1 Students of SMA Negeri 2 Bangko Kabupaten Rokan Hilir)

\section{Oleh: Romawati*)}

*) Guru Matematika SMA Negeri 2 Bangko Kabupaten Rokan Hilir

\begin{abstract}
Students' success in learning math is largely determined by the achievement of the learning process and requires the participation of students in writing. This study aims to improve students' mathematics learning outcomes of grade X SMA public 2 Bangko Semester Odd Year 2016/2017 on the subject matter of Equation and Quadratic Inequality by implementing QSH strategy in direct learning. This research includes collaborative classroom action research. Implementation of the research conducted in SMA public 2 Bangko Rokan Hilir Regency in the odd semester of the academic year 2016/2017. The research subjects of class X2 students as many as 26 people. This study consists of two cycles based on Arikunto (2010). Technique of data collection using observation sheet and test result of learning. Data analysis technique with descriptive statistical analysis. Implementation of QSH strategy in direct learning can improve mathematics learning outcomes of students of class X SMA public 2 Bangko academic year 2016/2017, especially on the subject matter of equations and quadratic inequalities.
\end{abstract}

Kata kunci: $Q S H$, direct learning, learning outcomes, mathematics

\section{PENDAHULUAN}

Matematika adalah ilmu yang berperan penting dalam berbagai disiplin ilmu perkembangan teknologi maupun sains. Dengan belajar matematika, secara tidak langsung akan meningkatkan pola pikir manusia. Melihat besarnya peran ilmu matematika, maka sangat penting untuk menguasai matematika itu sendiri.

Keberhasilan siswa mempelajari matematika sangat ditentukan oleh ketercapaian proses pembelajaran.Dengan kata lain apabila proses pembelajaran matematika baik, maka diharapkan siswa akan mencapai hasil belajar matematika yang baik. Hasil belajar matematika yang diharapkan setiap sekolah adalah hasil belajar matematika yang mencapai ketuntasan. Siswa matematika. dikatakan tuntas belajar matematika apabila hasil belajar matematika siswa telah mencapai Kriteria Ketuntasan Minimum (KKM) yang ditetapkan sekolah.

Kenyataan yang terjadi di lapangan, hasil belajar matematika siswa kelas X SMA Negeri 2 Bangko pada ulangan harian I semester ganjil tahun pelajaran 2013/2014 yaitu pada materi Akar, Pangkat dan Logaritma masih rendah. Hal ini dapat terlihat dari adanya siswa yang belum mencapai Kriteria Ketuntasan Minimum (KKM) yang ditetapkan sekolah yaitu 70. Siswa yang belum mencapai KKM adalah sebanyak 14 orang dari 26 orang siswa $(53,85 \%)$.

Berdasarkan hasil evaluasi terhadap proses pembelajaran di kelas $\mathrm{X}$ SMA Negeri 2 Bangko, terlihat bahwa 
guru melakukan metode pembelajaran yang hampir sama setiap kali mengajar, yaitu menjelaskan materi, memberi contoh soal, memberi latihan, dan penugasan. Guru pernah membentuk siswa bekerja dalam kelompok, namun dalam kelompok tersebut tidak tercipta kerjasama antar siswa. Hasil observasi juga menunjukkan bahwa siswa tergolong pasif, hanya beberapa orang siswa saja yang aktif bertanya dan menjawab, sedangkan yang lainnya hanya diam. Sikap siswa yang tidak mau bertanya tersebut menyebabkan guru tidak tahu dimana letak ketidakmengertian siswa terhadap materi pelajaran yang baru dijelaskan.

Berdasarkan pengalaman mengajar, guru juga melakukan diskusi dengan guru matematika kelas $\mathrm{X}$ yang lain (teman sejawat). Teman sejawat mengatakan bahwa berdasarkan pengalaman mengajar, materi yang perolehan hasil belajarnya selalu rendah adalah materi persamaan dan pertidaksamaan kuadrat, terutama pada materi aplikasi persamaan dan pertidaksamaan kuadrat. Selain wawancara dengan teman sejawat, guru juga melakukan wawancara dengan beberapa orang siswa kelas X SMA Negeri 2 Bangko sehingga diperoleh informasi bahwa sebagian siswa merasa takut untuk bertanya, sebagian lagi merasa malu, dan ada juga yang tidak bisa mengungkapkan pertanyaan secara lisan walaupun ada hal yang tidak dipahaminya. Kondisi seperti ini apabila terus menerus berlangsung, tentunya akan berpengaruh terhadap tingkat pemahaman siswa dan hasil belajarnya.

Berdasarkan latar belakang dan kondisi di atas, perlu diterapkan suatu strategi pembelajaran yang dapat mengaktifkan siswa dalam proses pembelajaran, sehingga siswa dapat aktif mengemukakan gagasannya, baik itu mengajukan pertanyaan ataupun menjawab pertanyaan dari teman sekelasnya. Salah satu strategi yang dapat mengaktifkan siswa adalah strategi belajar aktif. Strategi belajar aktif ada 101 cara, dan salah satunya adalah strategi Questions Students Have (QSH) (Silberman. 2006). Strategi ini memungkinkan siswa yang kurang berani mengajukan pertanyaan secara lisan untuk dapat menuliskan semua kesulitannya terhadap materi pelajaran. Dengan demikian, guru akan dapat mengetahui letak permasalahan siswa, dan akan berusaha menjawab permasalahan tersebut.

Penelitian ini bertujuan untuk meningkatkan hasil belajar matematika siswa kelas X SMA Negeri 2 Bangko Semester Ganjil Tahun Pelajaran 2016/2017 pada materi pokok Persamaan dan Pertidaksamaan Kuadrat dengan menerapkan strategi QSH dalam pembelajaran langsung.

\section{KAJIAN PUSTAKA \\ Hasil Belajar Matematika}

Hasil belajar adalah kemampuan yang dimiliki siswa setelah melalui serangkaian kegiatan belajar mengajar yang dinyatakan dalam bentuk angka atau skor yang diperoleh dari hasil tes yang dilaksanakan. Syarif (2009) mengatakan bahwa hasil belajar matematika merupakan kemampuan yang dimiliki siswa setelah belajar matematika. Hasil belajar matematika yang dimaksud dalam penelitian ini adalah kemampuan yang dimiliki siswa kelas X SMA Negeri 2 Bangko semester ganjil tahun pelajaran 2016/2017 setelah menerapkan strategi QSH dalam pembelajaran langsung pada materi pokok Persamaan dan Pertidaksamaan Kuadrat, dengan dilakukannya tes dan dinyatakan dalam bentuk angka atau skor.

\section{Model Pembelajaran Langsung}

Model pembelajaran langsung adalah model pembelajaran yang dirancang secara khusus untuk mengembangkan belajar siswa tentang pengetahuan prosedural dan pengetahuan deklaratif yang terstruktur dengan baik dan dapat dipelajari selangkah demi selangkah. Pengetahuan deklaratif adalah pengetahuan tentang sesuatu, 
sedangkan pengetahuan prosedural adalah pengetahuan tentang bagaimana melakukan sesuatu (Kardi dan Nur. 2000).

\section{Strategi Questions Student Have (QSH)}

Zaini (2004) mengatakan bahwa QSH merupakan strategi yang dapat dipakai untuk mengetahui kebutuhan dan harapan siswa. Strategi ini menggunakan partisipasi siswa secara tertulis.

\section{METODE PENELITIAN}

Penelitian ini termasuk penelitian tindakan kelas kolaboratif. Pelaksanaan penelitian dilakukan di SMA Negeri 2 Bangko Kabupaten Rokan Hilir pada semester ganjil tahun pelajaran 2016/2017. Penelitian ini terdiri dari dua siklus. Pada siklus pertama dilakukan tindakan yang mengacu pada langkah-langkah penerapan strategi QSH dalam pembelajaran langsung. Siklus kedua berupa tindakan berdasarkan hasil refleksi dari siklus pertama. Setiap siklus memiliki 4 tahap yaitu perencanaan, pelaksanaan, pengamatan dan refleksi. Bagan Siklus Penelitian Tindakan Kelas berdasarkan Arikunto (2010).

Subjek dari penelitian ini adalah siswa kelas $\mathrm{X}_{2}$ SMA Negeri 2 Bangko berjumlah 26 orang yang terdiri dari 11 orang lakilaki dan 15 orang perempuan. Kemampuan akademis siswa di kelas ini heterogen. Instrumen penelitian meliputi perangkat pembelajaran dan instrumen pengumpulan data. Teknik pengumpulan data menggunakan lembar pengamatan dan tes hasil belajar. Teknik analisis data yang digunakan adalah analisis statistik deskriptif.

\section{HASIL DAN PEMBAHASAN Siklus Pertama}

Siklus pertama dilakukan sebanyak tiga kali pertemuan dengan satu kali ulangan harian (ulangan harian I)

1) Pertemuan Pertama

Berdasarkan hasil pengamatan pertemuan pertama ini, siswa masih banyak yang bingung dalam mengerjakan
LTS dan membuat pertanyaan. Pada kelompok 1 ada dua pertanyaan yang paling banyak mendapat tanda cheklist, jadi guru memilih salah satu pertanyaan yang akan dibahas. Pada pertemuan pertama ini guru banyak menghabiskan waktu pada apersepsi dan fase mendemonstrasikan. Waktu juga banyak habis pada saat siswa membuat pertanyaan dan pada waktu menjawab pertanyaaan. Masih ada beberapa siswa yang kesulitan untuk menuliskan pertanyaannya. Banyaknya waktu yang terpakai pada fase tersebut menyebabkan latihan lanjutan tidak selesai dikerjakan. Selain itu, soal yang sudah disiapkan untuk penilaian tidak sempat dikerjakan. Di akhir pertemuan pertama ini guru merencanakan untuk memindahkan seorang siswa laki-laki yang punya penyakit mata. Siswa tersebut akan dipindahkan ke barisan paling depan dengan tujuan supaya dapat melihat tulisan di papan tulis.

2) Pertemuan Kedua

Pada pertemuan kedua ini, hanya ada beberapa siswa yang tidak selesai mengerjakan latihan lanjutan. Namun, soal untuk penilaian masih tidak bisa diberikan karena keterbatasan waktu.

3) Pertemuan Ketiga

Beberapa siswa mengeluh karena merasa terlalu banyak yang harus dikerjakan. Mereka mengatakan bahwa sudah mengerjakan LKS, LTS, latihan lanjutan, dan sekarang mengapa ada lagi soal yang harus dikerjakan. Guru berusaha menerangkan bahwa soal tersebut adalah soal penilaian yang dimaksudkan untuk menilai sebatas mana pemahaman siswa terhadap materi pada hari ini. Di akhir proses pembelajaran, guru menyampaikan bahwa pertemuan berikutnya akan diadakan ulangan harian I. Jadi, siswa harus giat belajar.

4). Pelaksanaan Ulangan harian I

Setelah tiga kali pertemuan guru melaksanakan ulangan harian I dengan memberikan tes hasil belajar untuk materi persamaan dan pertidaksamaan kuadrat. Tes dilaksanakan selama 2x40 menit. Soal 
terdiri dari 4 soal sesuai dengan indikator yang telah direncanakan oleh guru.

Pada saat pelaksanaan ulangan harian I, siswa tetap duduk ditempat masing-masing. Pada 10 menit pertama, siswa tampak tenang mengerjakan soal yang diberikan. Setelah itu, ada beberapa siswa yang tampak gelisah. Beberapa siswa memandang kanan dan kiri berusaha melihat kertas jawaban temannya. Guru memberikan peringatan agar semua siswa mengerjakan soalnya masing-masing, siswa tampak tenang kembali. Beberapa menit kemudian, ada siswa yang berusaha mencontoh pekerjaan teman di sebelahnya. Namun teman di sebelahnya tidak mau pekerjaannya dicontoh, akibatnya terjadi keributan antar siswa tersebut. Guru segera memberi peringatan bahwa siswa yang mencontoh akan diambil kertas jawabannya atau dikurangi skornya. Siswa tampak tenang kembali.

Pada saat 5 menit sebelum waktu habis, guru menyuruh siswa memeriksa kembali jawabannya dan mengingatkan siwa agar jangan lupa menuliskan nama pada lembar jawaban. Setelah waktu yang ditetapkan selesai semua siswa mengumpulkan lembar jawabannya.

b. Refleksi Siklus Pertama

Berdasarkan pengamatan selama melakukan tindakan sebanyak tiga kali pertemuan, banyak sekali kekurangankekurangan yang dilakukan oleh guru dan siswa. Kekurangan-kekurangan tersebut antara lain:

1) Waktu untuk mengerjakan soal penilaian sangat sedikit, hal ini disebabkan banyaknya waktu yang terpakai pada fase pertama sampai fase kelima

2) Pada saat membuat pertanyaan masih ada siswa yang bingung membuat pertanyaan.

3) Masih ada siswa yang hanya menyalin pertanyaan teman di sebelahnya.

4) Masih ada pertanyaan yang tidak sesuai dengan yang diharapkan.
5) Hanya beberapa siswa yang aktif menjawab pertanyaan

Berdasarkan refleksi siklus I, peneliti menyusun rencana perbaikan sebagai berikut:

1) Mengatur waktu agar lebih efektif sehingga proses pembelajaran berikutnya dapat berjalan dengan baik dan sesuai dengan yang direncanakan dalam RPP.

2) Memberikan arahan bagaimana membuat pertanyaan yang baik.

3) Berusaha membuat siswa lebih aktif dengan menambah penguatan berupa tambahan nilai bagi siswa yang berhasil menjawab pertanyaan.

4) Meningkatkan kemampuan pengelolaan kelas, misalnya memberikan peringatan kepada siswa yang tidak serius, dan memberikan penguatan kepada siswa yang berani menjawab pertanyaan, serta berusaha memberikan bimbingan yang merata.

\section{Siklus Kedua}

Siklus kedua dilakukan tiga kali pertemuan dan satu kali ulangan harian. Pada siklus kedua ini peneliti masih tetap menerapkan langkah-langkah pembelajaran pada siklus pertama dengan memperbaiki kekurangan-kekurangan berdasarkan refleksi siklus pertama.

1) Pertemuan Keempat

Pada pertemuan keempat ini siswa tidak lagi mengeluh tentang banyaknya soal yang harus dikerjakan. Di akhir pembelajaran guru bersama siswa menyimpulkan pelajaran hari ini.

2). Pertemuan Kelima

Setelah selesai mengerjakan LTS, siswa langsung menuliskan pertanyaan pada kertas pertanyaan yang sudah dibagikan. Pada saat ini siswa terlihat sudah dapat membuat soal dengan baik. Setelah itu mereka langsung memberikan pertanyaannya kepada teman di samping kiri agar teman tersebut dapat membaca dan mencheklist jika ingin mengetahui 
jawabannya. Setelah pertanyaan kembali kepada pemiliknya, guru menginstruksikan kepada siswa agar membacakan pertanyaan yang mendapat tanda cheklist yang paling banyak. Setelah dibacakan, guru meminta kelompok lain menjawab pertanyaan. Pertanyaan kelompok satu adalah bagaimana jika pada LTS-5 nomor 2, nilai $\alpha$ diganti menjadi $x_{2}-3$. Pertanyaan kelompok dua sama dengan pertanyaan kelompok lima, yaitu apa maksud akar-akarnya merupakan kebalikan dari akar-akar persamaan $x^{2}-3 x+4=0$. Pertanyaan kelompok tiga yaitu bagaimana cara menentukan nilai $\alpha$ dan $\beta$ pada LTS-5 nomor 1 . Pertanyaan kelompok empat adalah bagaimana menentukan $\alpha$ dan $\beta$ dari LTS5 nomor 3. Kelompok satu menjawab pertanyaan kelompok tiga, dan kelompok lima menjawab pertanyaan kelompok satu. Karena tidak ada lagi siswa yang mau menjawab pertanyaan, maka pertanyaan kelompok empat dan kelompok dua yang berarti juga pertanyaan kelompok lima dijawab oleh guru.

\section{3). Pertemuan Keenam}

Setelah pengerjaan LTS, siswa langsung menuliskan pertanyaan mereka pada kertas tersebut. Pada saat ini siswa terlihat sudah dapat membuat soal dengan baik. Setelah semua siswa selesai membuat pertanyaan, mereka langsung memberikan pertanyaannya kepada teman di samping kiri agar teman tersebut dapat membaca dan mencheklist jika ingin mengetahui jawabannya. Setelah pertanyaan kembali kepada pemiliknya, kemudian guru menginstruksikan kepada siswa agar membacakan pertanyaan yang mendapat tanda cheklist yang paling banyak. Kelompok satu, tiga, dan empat memiliki pertanyaan yang sama, yaitu pada LTS-6 nomor 1, mengapa kedua ruas dibagi 15.000. Pertanyaan kelompok dua adalah pada LTS-6 nomor 1, mengapa nilai $x$ yang diambil adalah nilai $x$ yang positif. Pertanyaan kelompok lima adalah pada LTS-6 nomor 1, mengapa kedua ruas dikali $x(x+5)$. Guru meminta kelompok lain menjawab. Kelompok lima menjawab pertanyaan dari kelompok satu, yang artinya pertanyaan kelompok tiga dan empat juga terjawab. Petanyaan yang belum terjawab dijawab oleh guru.

4). Pelaksanaan ulangan harian II

$$
\text { Pada pertemuan ini guru }
$$
memberikan ulangan harian II yang dilaksanakan setelah tiga kali pertemuan. Tes dilaksanakan selama $2 \times 40$ menit. Pada pelaksanaan ulangan harian II untuk menghindari kerja sama antar siswa, guru lebih meningkatkan pengawasan dan memberi peringatan bahwa siswa yang kedapatan mencontoh akan dicatat namanya dan akan dikurangi nilainya.

Setelah satu jam berjalan, ada bebarapa siswa yang gelisah dan berusaha melihat kertas jawaban temannya. Guru segera memberi peringatan keras bahwa yang mencontoh akan diambil kertas jawabannya. Siswa tenang kembali dan mulai lagi mengerjakan masing-masing.

Setelah waktu ujian selesai, guru meminta siswa mengumpulkan kertas jawaban. Kemudian guru menyampaikan kepada siswa bahwa pelaksanaan pembelajaran dengan strategi QSH pada materi Persamaan dan Pertidaksamaan telah selesai. Guru mengucapkan terima kasih kepada semua siswa yang telah mengikuti pelaksanaan pembelajaran dengan menggunakan strategi QSH. Guru berpesan agar siswa meningkatkan lagi intensitas belajar untuk menghadapi ujian semester.

\section{d. Refleksi Siklus Kedua}

Siklus kedua sudah berjalan lebih baik dari siklus pertama. Siswa sudah terbiasa dan mengerti dengan langkahlangkah pembelajaran, sehingga tidak terlalu banyak melakukan kesalahan. Sudah mulai banyak siswa yang aktif dibandingkan siklus I walaupun guru harus selalu memberikan motivasi agar siswa aktif dalam proses pembelajaran. Pada siklus kedua ini peneliti tidak melakukan perencanaan untuk siklus berikutnya, hasil refleksi siklus kedua ini peneliti serahkan 
kepada guru sebagai bahan masukan untuk perbaikan ke depan.

\section{Analisis Hasil Tindakan \\ 1. Aktivitas guru dan siswa}

Aktivitas guru dan siswa dalam penerapan strategi QSH diketahui berdasarkan pengamatan terhadap aktivitas guru dan siswa selama proses pembelajaran berlangsung. Pada pertemuan pertama, proses pembelajaran belum sesuai dengan perencanaan walaupun peneliti sudah cukup berusaha agar pelaksanaan sesuai dengan rencana. Ada beberapa kesalahan yang dilakukan guru pada pertemuan pertama, yaitu guru terlalu lama dalam menyampaikan apersepsi, guru masih mendominasi, penggunaan waktu kurang efektif sehingga latihan lanjutan dan penilaian tidak terlaksana. Kendala yang ditemui pada pertemuan pertama ini diantaranya adalah siswa masih bingung dengan apa yang akan mereka kerjakan, siswa bingung dalam mengerjakan LTS. Pada pertemuan kedua, kelemahankelemahan pada pertemuan pertama sudah diperbaiki. Dalam mendemonstrasikan pengetahuan melalui LKS, guru mampu memancing siswa untuk aktif. Siswa juga mulai lancar dalam mengerjakan LTS dengan berpedoman pada LKS. Namun masih ada juga kendala ditemukan yaitu pada saat menuliskan pertanyaan masih banyak siswa yang bingung dan tidak tahu pertanyaan apa yang akan mereka ajukan. Pada pertemuan ketiga, aktivitas guru dan siswa sudah hampir sesuai dengan RPP. Pada pertemuan keempat, siswa sudah mulai terbiasa dengan pembelajaran dengan strategi QSH. Pertemuan kelima dan keenam, berdasarkan hasil pengamatan terlihat aktivitas guru dan siswa telah terlaksana sesuai dengan RPP. Secara garis besar, aktivitas siswa sudah semakin baik, siswa sudah terbiasa bekerja dalam kelompok dalam mengerjakan LTS, siswa sudah terbiasa mengerjakan latihan lanjutan dan soal penilaian secara individu. 2. Ketercapaian KKM Setiap Indikator Ketuntasan hasil belajar matematika siswa untuk setiap indikator dianalisis. Siswa dikatakan tuntas apabila memperoleh nilai 60 untuk setiap indikator. Ketercapaian KKM untuk setiap indikator pada ulangan harian I disajikan dalam tabel berikut.

Tabel 1. Ketercapaian KKM pada Ulangan Harian I untuk Setiap Indikator

\begin{tabular}{clcc}
\hline No & \multicolumn{1}{c}{ Indikator Ketercapaian } & Jumlah Siswa & Persentase \\
\hline 1 & Menentukan akar-akar persamaan kuadrat & 17 & $65,4 \%$ \\
\hline 2 & $\begin{array}{l}\text { Menentukan jenis akar-akar persamaan } \\
\text { kuadrat }\end{array}$ & 26 & $100 \%$ \\
\hline 3 & $\begin{array}{l}\text { Menggunakan rumus jumlah dan hasil kali } \\
\text { akar-akar persamaan kuadrat }\end{array}$ & 22 & $84,6 \%$ \\
\hline 4 & $\begin{array}{l}\text { Menentukan himpunan penyelesaian } \\
\text { pertidaksamaan kuadrat }\end{array}$ & 11 & $42,3 \%$ \\
\hline
\end{tabular}

Berdasarkan uraian di atas, tidak semua siswa mencapai KKM untuk setiap indikator. Hal ini terjadi karena secara umum siswa kurang teliti dalam menyelesaikan soal yang diberikan.
Namun demikian, ketercapaian KKM untuk seluruh indikator pada ulangan harian I dari 26 orang siswa terdapat 18 orang siswa yang mencapai KKM dengan persentase $69,2 \%$.

Tabel 2.Ketercapaian KKM pada Ulangan Harian II untuk Setiap Indikator

\begin{tabular}{clcc}
\hline No & \multicolumn{1}{c}{ Indikator Ketercapaian } & Jumlah Siswa & Persentase \\
\hline 1 & $\begin{array}{l}\text { Menyusun persamaan kuadrat yang diketahui } \\
\text { akar-akarnya }\end{array}$ & 24 & $92,3 \%$ \\
\hline 2 & $\begin{array}{l}\text { Menyusun persamaan kuadrat berdasarkan } \\
\text { akar-akar persamaan kuadrat lain }\end{array}$ & 13 & $50 \%$ \\
\hline 3 & Menentukan penyelesaian masalah aplikasi & 3 & $11,5 \%$ \\
\hline
\end{tabular}


persamaan dan pertidaksamaan kuadrat.

Berdasarkan uraian di atas, tidak semua siswa mencapai KKM untuk setiap indikator. Hal ini terjadi karena secara umum siswa kurang teliti mencermati soal yang diberikan dan salah dalam melakukan operasi hitung. Namun demikian, ketercapaian KKM untuk seluruh indikator pada ulangan harian II sudah tercapai, dari 26 orang siswa terdapat 16 orang siswa yang memperoleh nilai $\geq 60$ dengan persentase $61,5 \%$.

Untuk ketercapaian KKM indikator pada ulangan harian I, pada tabel 2 dapat dilihat bahwa untuk indikator 1 jumlah siswa yang mencapai KKM indikator hanya 17 siswa $(65,4 \%)$. Dari analisis lembar jawaban ulangan harian I, sebagian siswa tidak mampu menyelesaikan perkalian suku. Untuk indikator 2, semua siswa mencapai KKM indikator. Untuk indikator 3, siswa yang mencapai KKM indikator adalah sebanyak 22 orang $(84,6 \%)$. Untuk indikator 4 , siswa yang mencapai KKM indikator hanya 11 orang $(42,3 \%)$. Dari analisis lembar jawaban ulangan harian I, banyak siswa yang tidak mampu menguji titik pada setiap interval. Siswa tersebut hanya mengerjakan sampai tahap menentukan akar-akar persamaan kuadrat.

Untuk ketercapaian KKM indikator untuk ulangan harian II, pada tabel 3 dapat dilihat bahwa untuk indikator 1, siswa yang mencapai KKM indikator adalah sebanyak 24 orang $(92,3 \%)$. Pada indikator 1 ini, hampir semua siswa mencapai KKM indikator. Untuk indikator 2, siswa yang mencapai KKM indikator adalah 13 siswa $(50 \%)$. Dari analisis lembar jawaban ulangan harian II, banyak siswa yang tidak dapat menentukan jumlah dan hasil kali dari akar-akar persamaan kuadrat baru yang akan dicari. Siswa tersebut hanya mengerjakan sampai tahap menentukan akar-akar persamaan kuadrat baru berdasarkan akar-akar persamaan kuadrat yang diketahui. Untuk indikator 3, siswa yang mencapai KKM indikator hanya 3 orang (11,5\%). Dari analisis lembar jawaban ulangan harian II, sebagian besar siswa tidak mampu menguji titik, menentukan interval, dan menentukan himpunan penyelesaian. Sebagian siswa hanya mengerjakan sampai tahap menentukan akar-akar persamaan kuadrat, dan ada pula yang mengerjakan sampai tahap mengubah soal cerita ke dalam model matematika.

\section{Keberhasilan Tindakan}

Peningkatan hasil belajar siswa dapat dilihat dengan membandingkan nilai siswa setelah tindakan dengan nilai dasar. Keberhasilan tindakan dapat dilihat pada tabel berikut.

Tabel 3. Daftar Distribusi Frekuensi Nilai Hasil Belajar

\begin{tabular}{cccc}
\hline Interval & \multicolumn{3}{c}{ Banyak Siswa } \\
\cline { 2 - 4 } & Sebelum Tindakan & Siklus I & Siklus II \\
\hline $24-35$ & 2 & 1 & $\mathbf{0}$ \\
\hline $36-47$ & 3 & 6 & 1 \\
\hline $48-59$ & 9 & 1 & 9 \\
\hline $60-71$ & 7 & 3 & 6 \\
\hline $72-83$ & 4 & 12 & 2 \\
\hline $84-95$ & 1 & 26 & 26 \\
\hline$\sum f$ & 26 & 18 & $61,5 \%$ \\
\hline Jumlah siswa yang mencapai KKM 60 & 12 & $69,2 \%$ & 16 \\
\hline
\end{tabular}


Untuk keberhasilan tindakan, hasil belajar matematika siswa menunjukkan peningkatan. Hasil belajar matematika siswa sudah lebih baik dibandingkan hasil belajar pada materi pokok sebelumnya. Dari analisis data tentang keberhasilan tindakan diperoleh fakta bahwa terjadi peningkatan jumlah siswa yang memperoleh nilai di atas KKM sesudah tindakan dibandingkan dengan jumlah siswa yang memperoleh nilai di atas KKM sebelum tindakan dengan persentase ketuntasan pada Ulangan Harian I adalah 69,2 \% dan 61,5\% pada ulangan harian II. Persentase ketuntasan pada skor dasar adalah 42,2\% meningkat menjadi $69,2 \%$. Namun, persentase ketuntasan dari ulangan harian I menurun pada ulangan harian II menjadi $61,5 \%$. Hal ini terjadi karena materi pada siklus II lebih sukar daripada materi pada siklus I, sehingga tingkat kesulitan soal pada ulangan harian II lebih tinggi daripada soal ulangan harian I. Namun demikian, persentase ketuntasan pada ulangan harian II lebih tinggi daripada persentase ketuntasan pada skor dasar. Dengan demikian, dapat dikatakan bahwa persentase ketuntasan setelah tindakan lebih tinggi daripada persentase ketuntasan sebelum tindakan.

Berdasarkan pengamatan peneliti, penerapan strategi QSH dalam pembelajaran langsung semakin lama semakin sesuai dengan perencanaan pembelajaran. Hal ini dapat dilihat dari proses pembelajaran yang semakin lama menjadi semakin baik. Selama proses pembelajaran berlangsung, terlihat aktivitas dan interaksi siswa dalam kelompok semakin baik. Terlihat siswa semangat dan aktif dalam proses pembelajaran. Adanya LKS membuat siswa aktif dan mampu memahami konsep setahap demi setahap. LTS dan latihan lanjutan melatih siswa untuk mahir dalam mengerjakan soal. Sedangkan kertas pertanyaan sangat berguna untuk mengungkapkan kesulitan siswa terhadap materi pelajaran, sehingga dengan terjawabnya pertanyaan, maka akan meningkatkan pemahaman siswa terhadap materi pelajaran.

Selama proses penelitian di kelas X SMA Negeri 2 Bangko ada beberapa hal yang menjadi kendala dalam penelitian diantaranya: pada pertemuan pertama siswa masih bingung dengan model pembelajaran yang diterapkan. Kekurangan ini menurut peneliti karena siswa belum terbiasa dengan penerapan strategi QSH dalam pembelajaran langsung dan berdasarkan hasil pengamatan guru masih kurang dalam mensosialisasikan teknik pembelajaran yang digunakan dalam penelitian ini. Selain itu, guru juga masih kurang dalam pengelolaan kelas, misalnya dalam menyikapi siswa yang tidak serius, siswa yang mengantuk, bercanda, dan sebagainya.

\section{KESIMPULAN DAN SARAN}

Penerapan strategi QSH dalam pembelajaran langsung dapat meningkatkan hasil belajar matematika siswa kelas X SMA Negeri 2 Bangko tahun pelajaran 2016/2017 khususnya pada materi pokok persamaan dan pertidaksamaan kuadrat.

Disarankan dalam penerapan strategi QSH dalam pembelajaran langsung dalam pembelajaran matematika guru harus mensosialisasikan strategi pembelajaran yang akan digunakan secara jelas kepada siswa sehingga siswa tidak kebingungan pada saat melaksanakan proses pembelajaran. Guru hendaknya menyediakan waktu untuk membahas pertanyaan-pertanyaan yang tidak dibahas dalam setiap pertemuan. Guru hendaknya membimbing kelompok untuk mengoptimalkan kerjasama anggota-anggotanya, dan memberikan pengarahan yang baik dalam hal membuat dan mencheklist pertanyaan.

\section{DAFTAR PUSTAKA}

Arikunto. 2010. Prosedur Penelitian Suatu Pendekatan Praktik. Rineka Cipta. Jakarta

Kardi dan Nur. 2000. Pengajaran Langsung. UNESA University Press. Surabaya

Silberman, Melvin L. 2006. Active Learning 101 Cara Belajar Siswa Aktif. Remaja

Rosdakarya. Bandung 
Syarif. 2009. Hasil Belajar dan Pembelajaran. Alfabeta. Bandung

Zaini. 2004. Strategi Pembelajaran Aktif. Pustaka pelajar. Yogyakarta 